\title{
Analisis Komparatif Kinerja Keuangan dengan Metode Risk Profile, Good Corporate Governance, Earning, Capital (RGEC) pada Bank Umum Pemerintah di Bursa Efek Indonesia
}

\author{
Jusmani ${ }^{1}$, Emma Lilianti ${ }^{2}$ \\ ${ }^{1}$ Akuntansi, Fakultas Ekonomi, Univ. PGRI Palembang, jusmani@univpgri-palembang.ac.id \\ ${ }^{2}$ Akuntansi, Fakultas Ekonomi, Univ. PGRI Palembang emmaliliantiok@gmail.com
}

\begin{abstract}
ABSTRAK
Tujuan dari penelitian ini untuk mengetahui bagaimana perbandingan kinerja keuangan Bank Umum Pemerintah (BUMN) yang terdiri dari Bank BRI, Bank BNI, Bank Mandiri dan Bank BTN periode 20152017. Metode yang digunakan dalam penelitian ini adalah Metode RGEC yang terdiri dari Risk Profile, Good Corporate Governance, Earning, Capital. Analisis data deksriptif kuantitatif dengan menganalisis rasio : Risk Profile menggunakan rasio NPL (Non Performing Loan) dan LDR (Loan to Deposit Ratio), Good Corporate Governance, Earning dengan menggunakan rasio ROA (Return On Asset), NIM (Net Interest Margin), dan Capital dengan menggunakan rasio CAR (Capital Adequency Ratio). Hasil penelitian menunjukkan bahwa Bank BRI dan Mandiri memiliki kinerja yang lebih baik ditinjau dari pengelolaan risiko kredit, risiko likuiditas. Aspek Good Corporate Governance secara keseluruhan Bank BUMN sudah menerapkan tata kelola perusahaan dengan sangat baik. Dilihat dari aspek rentabilitas dan aspek permodalan semua Bank BUMN mampu menghasilkan laba, kestabilan komponen-komponen yang mendukung core earning, dan mampu meningkatkan permodalan dan prospek laba di masa depan.
\end{abstract}

Kata Kunci : NPL, LDR, GCG, ROA, NIM, CAR.

\section{A. Pendahuluan}

Salah satu sektor yang paling berpengaruh dalam menggerakkan roda perekonomian adalah sektor perbankan.

Berdasarkan kepemilikannya, bank umum di Indonesia dapat dibedakan menjadi bank milik pemerintah, bank milik swasta nasional, bank milik koperasi, bank milik asing dan milik campuran. Sektor perbankan merupakan pilar dalam membangun system perekonomian dan keuangan Indonesia karena perbankan memiliki peran sebagai intermediary institution yaitu lembaga keuangan yang menghubungkan dana-dana yang dimiliki oleh unit ekonomi yang surplus kepada unit-unit ekonomi yang membutuhkan bantuan dana (deficit). Salah satu sektor yang paling berpengaruh dalam menggerakkan roda perekonomian adalah sektor perbankan.

Berdasarkan kepemilikannya, bank umum di Indonesia dapat dibedakan menjadi bank milik pemerintah, bank milik swasta nasional, bank milik koperasi, bank milik asing dan milik campuran. Bank umum pemerintah terdiri dari bank milik Negara dan milik pemerintah daerah. Bank milik pemerintah merupakan bank yang sebagian atau keseluruhan sahamnya dimiliki oleh pemerintah dan umumnya berstatus sebagai bank BUMN. Bank BUMN terdiri dari Bank Rakyat Indonesia (BRI), Bank Negara Indonesia (BNI), Bank Mandiri, dan Bank Tabungan Negara (BTN).

$$
\text { Perbankan di Indonesia }
$$

berkembang sangat cepat, fungsi bank-bank di tersebut sebagai badan tempat masyarakat dengan mudah menyimpan uang mereka dalam bentuk tabungan. Dengan adanya bank suatu kegiatan yang terkait transaksi keuangan menjadi lebih praktis dan efektif. Dalam rangka mencapai sistem perbankan yang kuat, sehat serta efisien maka Bank Indonesia sebagai lembaga pengawas 
dan regulator perbankan melakukan proses konsolidasi terhadap perbankan Indonesia yang bertujuan untuk meningkatkan ketahanan dan kesehatan perbankan dalam jangka panjang. Kesehatan bank merupakan kemampuan suatu bank untuk melakukan kegiatan operasi perbankan secara normal dan mampu memenuhi semua kewajibannya dengan baik dan dengan cara-cara yang sesuai dengan peraturan perbankan yang berlaku.

Berdasarkan surat edaran Deputi Gubernur Bank Indonesia nomor 6/23/DPNP tahun 2004 tentang sistem penilaian tingkat kesehatan Bank Umum. Bank Indonesia menetapkan suatu ketentuan yang harus dipenuhi dan dilaksanakan oleh lembaga perbankan. Dengan melakukan penilaian tingkat kesehatan bank yang digunakan adalah dengan metode CAMEL yang mencakup faktor-faktor Capital (permodalan), Asset (kualitasAset), Management (manajemen), Earning (rentabilitas), dan Liquidity (likuiditas). Bank Indonesia melakukan pengembangan metode CAMEL pada tanggal 25 Oktober 2011 menerbitkan peraturan tentang Penilaian Tingkat Kesehatan Bank Umum. Berdasarkan SE BI No.13/24/DPNP 2011 yang merupakan petunjuk pelaksanaan dari Peraturan Bank Indonesia No.13/1/PBI/2011 tanggal 5 Januari 2011, yang mewajibkan Bank Umum untuk melakukan penilaian sendiri (self assessment) atas Tingkat Kesehatan Bank dengan menggunakan pendekatan risiko (Risk-Bassed Bank Rating/RBRR), baik secara individual maupun secara konsolidasi yang penilaiannya dilakukan setiap triwulan, pada bulan Maret, Juni, September, dan Desember. Metode yang digunakan adalah RGEC yang mencakup komponen-komponen Risk Profile (Profil Risiko), Good Corporate
Governance (GCG), Earnings (Rentabilitas), dan Capital (Modal). Rasio yang digunakan dalam metode RGEC pada penelitian ini adalah NPL, LDR, ROA, NIM dan CAR. Beberapa bagian tampak masih sama seperti masih digunakan sistem penilaian Capital dan Earning. Adapun sistem penilaian Management pun diganti menjadi Good Corporate Governance. Sedangkan untuk komponen Asset Quality, Liquidity dan Sensitivity to Market Risk akhirnya dijadikan satu dalam komponen Risk Profile. Penelitian Mandasari, penelitian telah dilakukan pada keempat bank BUMN dan hasilnya aspek tata kelola keempat bank dikatakan dalam kondisi yang baik, ditinjaudari risk profile yang diwakili rasio likuiditas dikatakan baik, dan secara keseluruhan kinerja keuangan dari segi permodalan dikatakan baik. Penelitian Monika Basama, hasilnya bank BUMN memiliki kinerja yang lebih baik dari segi aspek pengelolaan tata kelola perusahaan dan rentabilitas, sedangkan bank nasional unggul dalam risiko likuiditas dan bank asing unggul pada aspek pengelolaan risiko kredit dan permodalan. Persamaan penelitian Norrahmiati menganalisis perbandingan kinerja keuangan berdasarkan metode RGEC. Penelitian Basama (2017) Analisis Perbandingan Tingkat Kesehatan Bank dengan Metode RGEC pada Bank Swasta Nasional dan Bank Asing. Penelitian Daniswara (2016) berjudul Analisis Perbandingan Kinerja Keuangan berdasarkan Risk Profile, Good Governance, Earning and Capital (RGEC) pada bank Umum Konvensional dan Bank Umum Syariah.

Berdasarkan latar belakang yang telah diuraikan diatas, rumusan masalah penelitian ini adalah: "Bagaimana perbandingan kinerja 
keuangan dengan metode Risk Profile, Good Corporate Governance, Earning, Capital (RGEC) pada Bank Umum Pemerintah di Bursa Efek Indonesia periode tahun 2015-2017?"

\section{B. Landasan Teori Bank}

Kasmir menyatakan (2014:24), bank dikenal sebagai lembaga keuangan yang kegiatan utamanya menerima simpanan giro, tabungan dan deposito.Kemudian bank juga dikenal sebagai tempat untuk meminjam uang (kredit) bagi masyarakat yang membutuhkannya.Di samping itu, bank juga dikenal sebagai tempat untuk menukar uang memindahkan uang atau menerima segala macam bentuk pembayaran dan setoran seperti pembayaran listrik, telepon, air, pajak, uang kuliah, dan pembayaran lainnya. Iskandar (2013:3) bank merupakan badan usaha yang bergerak dalam bidang jasa keuangan, yang berfungsi sebagai pengumpul dana, pemberi pinjaman, dan menjadi perantara dalam pembayaran giral. Ismail menyatakan (2011:4) fungsi utama bank adalah menghimpun dana dari masyarakat, menyalurkan dana kepada masyarakat, dan juga memberikan pelayanan dalam bentuk jasa perbankan.

Kasmir (2014:8), dalam praktiknya dibagi menjadi beberapa jenis. Jika ditinjau dari fungsinya, bank dikelompokkan menjadi tiga jenis, yaitu:

1. Bank sentral, merupakan bank yang mengatur berbagai kegiatan yang berkaitan dengan dunia perbankan dan dunia keuangan disuatu negara.

Contoh : Bank Indonesia

2. Bank umum, merupakan bank yang bertugas melayani seluruh jasa-jasa perbankan dan melayani segenap lapisan masyarakat, baik masyarakat perorangan maupun lembagalembaga lainnya.Contoh : Bank Mandiri, Bank BRI, Bank BNI dan lain-lain.

3. Bank Perkreditan Rakyat (BPR), merupakan bank yang khusus melayani masyarakat kecil di kecamatan dan pedesaan.

4. Bank Syariah merupakan lembaga keuangan yang usaha pokoknya adalah menghimpun dana dari masyarakat dan menyalurkannya dalam bentuk pembiayaan dan jasa lain dalam lalu lintas pembayaran serta peredaran uang, yang beroperasi sesuai dengan prinsip-prinsip syariah. Contoh : Bank Muamalat dan lain-lain.

\section{Kinerja Keuangan}

Fahmi (2017:239) menyatakan kinerja keuangan adalah suatu analisis yang dilakukan untuk melihat sejauh mana perusahaan telah melaksanakan dan menggunakan aturan-aturan pelaksanan keuangan dengan baik dan benar.Seperti membuat suatu laporan keuangan yang telah memenuhi standar dan ketentuan dalam SAK (Standar Akuntansi Keuangan), atau GAAP (General Acepted Accounting Principle), dan lainnya. Jumingan (2011:9) Kinerja keuangan Bank adalah gambaran kondisi keuangan perusahaan pada suatu periode tertentu baik menyangkut aspek penghimpunan dana maupun penyaluran dana yang biasanya diukur degan indikator kecukupan modal, likuiditas dan pofitabilitas bank.

Penilaian kinerja perusahaan, termasuk bank sering dikaitkan dengan rasio-rasio keuangan, di samping penilaian pergerakan harga saham dan return saham yang 
diperjualbelikan di bursa. Pengukuran kinerja bank yang dikaitkan dengan rasio-rasio keuangan diatur dalam regulasi perbankan yang diterbitkan oleh Bank Indonesia sebagai pengawas dan regulator sektor perbankan untuk menilai tingkat kesehatan suatu bank. Fahmi (2017: 245), menyatakan manfaat penilaian kinerja keuangan antara lain:

1. Untuk mengukur prestasi yang dicapai oleh suatu organisasi dalam suatu periode tertentu yang mencerminkan tingkat keberhasilan pelaksanaan kegiatannya.

2. Selain digunakan untuk melihat kinerja organisasi secara keseluruhan, maka pengukuran kinerja juga dapat digunakan untuk menilai kontribusi suatu bagian dalam pencapaian tujuan perusahaan secara keseluruhan.

3. Dapat digunakan sebagai penentuan strategi perusahaan untuk perusahaan dimasa yang akan datang.

4. Memberi petunjuk dalam pembuatan dan kegiatan organisasi pada umumnya dan divisi atau bagian organisasi pada khusunya.

5. Sebagai dasar penentuan kebijakan penanaman modal agar dapat menigkatkan efisiensi dan produktivitas perusahaan.

Teori Penilaian Bank (RGEC).

Penilaian Tingkat Kesehatan Bank Umum telah diatur dalam Peraturan Bank Indonesia No.13/PBI/2011 tentang tingkat kesehatan Bank Umum. Penilaian ini menggunakan metode RGEC yaitu penilaian kinerja keuangan bank dengan menggunakan pendekatan berdasarkan risiko (Risk Based Bank
Rating) merupakan penilaian yang komprehensif dan terstruktur terhadap hasil integrasi antara profil risiko dan kinerja yang meliputi penerapan tata kelola yang baik, rentabilitas, dan permodalan. Komponen tersebut akan dinilai berdasarkan analisis secara komperhensif dan terstruktur terhadap peringkat dengan mempehatikan faktor yang ditetapkan menjadi peringkat komposit.

Peringkat komposit ialah peringkat yang didapat dari hasil perhitungan dalam penilaian tingkat kesehata bank. Peringkat komposit sendiri dibagi menjadi lima peringkat, dimana masing-maing peringkat tersebut memiliki predikat mulai dari sangat sehat, sehat, cukup sehat, kurang sehat dan tidak sehat.

\section{a. $\quad$ Risk Profile (Profil Risiko)}

Profil Risiko merupakan penilaian terhadap Risiko inheren dan kualitaspenerapan Manajemen Risiko dalam aktivitas operasional Bank. Risiko yang wajib dinilai terdiri atas 8 (delapan) jenis Risiko yaitu Risiko Kredit, Risiko Pasar, Risiko Operasional, Risiko Likuiditas, Risiko Hukum, Risiko Stratejik, Risiko Kepatuhan, dan Risiko Reputasi (Peraturan Bank Indonesia No.13/PBI/2011).

Risiko merupakan faktor yang sangat berpengaruh dalam menjalankan usaha perbankan, maka dari itu Risk Profile adalah faktor yang penting dalam kesehatan bank. Penilaian terhadap risk profile dapat menggunakan beberapa rasio diantaranya Net Performing Loan (NPL) yaitu perbandingan antara jumlah kredit bermasalah dengan banyaknya dana bank yang disalurkan kepada masyarakat berupa kredit. 
$\mathrm{NPL}=\underline{\text { Kredit Bermasalah }} \times 100 \%$

Total Kredit

(Ismail $2010: 227$ )

Tabel 1. Kriteria Penetapan Peringkat Komponen Risiko Kredit

\begin{tabular}{|c|c|c|}
\hline Peringkat & Kriteria & Keterangan \\
\hline 1 & $<2 \%$ & Sangat Sehat \\
\hline 2 & $2 \%-3,5 \%$ & Sehat \\
\hline 3 & $3,5 \%-5 \%$ & Cukup Sehat \\
\hline 4 & $5 \%-8 \%$ & Kurang Sehat \\
\hline 5 & $>8 \%$ & Tidak Sehat \\
\hline
\end{tabular}

Sumber: Bank Indonesia

Kemudian indikator yang digunakan utuk mengukur risiko likuiditas dengan menggunakan rasio LDR (Loan to Deposit Ratio). Rasio ini digunakan untuk mengukur perbandingan antara jumlah kredit yang diberikan bank dengan jumlah dana pihak ketiga yang diperoleh oleh bank (DPK) melalui produk-produk keuangannya, yang menandakan kemampuan perusahaan dalam melakukan pembayaran kembali penarikan dana oleh masyarakat dengan sisa DPK yang tidak direalisasi sebagai kredit untuk dipergunakan sebagai sumber likuiditas.

LDR $=\underline{\text { Kredit Yang diberikan }} \times 100 \%$ Dana Pihak Ketiga

Tabel 2. Kriteria Penetapan Peringkat Komponen Risiko Likuiditas

\begin{tabular}{|c|c|c|}
\hline Peringkat & Kriteria & Keterangan \\
\hline 1 & $70 \%-<85 \%$ & Sangat Sehat \\
\hline 2 & $60 \%-<70 \%$ & Sehat \\
\hline 3 & $85 \%-<100 \%$ & Cukup Sehat \\
\hline 4 & $100 \%-120 \%$ & Kurang Sehat \\
\hline 5 & $>120 \%-<60 \%$ & Tidak Sehat \\
\hline
\end{tabular}

Sumber: Bank Indonesia

\section{b. Good Corporate Governance (GCG)}

Good Corporate Governance pada awalnya dianalisis berdasarkan Surat Edaran Bank Indonesia No.09/12/DPNP tahun 2011. Analisis dalam surat edaran tersebut menggunakan kertas kerja self assessment Good Corporate Governance yang dipublikasikan oleh Bank Indonesia. Seiring berjalannya waktu, Bank Indonesia kembali mengeluarkan Surat Edaran Bank Indonesia No.15/15/DPNP tahun 2013 tentang penilaian Good Corporate Governance.

Berdasarkan hal tersebut, sehingga dilakukan upaya perbaikan dan peningkatan kualitas pelaksanaan Good Corporate Governannce, yang mewajibkan bank secara berkala melakukan penilaian sendiri (self assessment) secara komprehensif terhadap kecukupan pelaksanaan Good Corporate Governance. Analisis Good Corporate Governance dikelompokkan dalam suatu governance system yang terdiri dari 3 
(tiga) aspek governance, yaitu governance structure, governance procesess, dan governance outcome.

\section{Earning (Rentabilitas)}

(Peraturan Bank Indonesia No.13/PBI/2011) Berikutnya mengenai aspek Earning dilihat dimana kemampuan bank dalam hal meningkatkan laba dan efektivitas yang dicapai oleh perusahaan dalam menghasilkan laba sebagai tujuan perusahaan. Rasio yang digunakan dalam Earningadalah rasio ROA (Return On Asset) yaitu perbandingan antara laba sebelum pajak dengan rata-rata total aset.

ROA $=\underline{\text { Laba Sebelum Pajak } \times 100 \%}$ Rata-rata Total Aktiva

Tabel 3. Kriteria Penetapan Peringkat Komponen Rentabilitas (ROA)

\begin{tabular}{|c|c|c|}
\hline Peringkat & Kriteria & Keterangan \\
\hline 1 & $>2 \%$ & Sangat Sehat \\
\hline 2 & $1,26 \%-2 \%$ & Sehat \\
\hline 3 & $0,51 \%-1,25 \%$ & Cukup Sehat \\
\hline 4 & $0 \%-0,5 \%$ & Kurang Sehat \\
\hline 5 & $<0 \%$ & Tidak Sehat \\
\hline
\end{tabular}

Sumber: Bank Indonesia

Rasio NIM (Net Interest Margin) merupakan perbandingan antara pendapatan bunga bersih dengan ratarata total aset produktif.Rasio ini digunakan untuk menunjukkan perbandingan antara pendapatan bunga bersih terhadap rata-rata total aset produktif.

$\mathrm{NIM}=\underline{\text { Pendapatan Bunga Bersih }} \times 100 \%$ Rata-rata Aktiva Produktif

(SE BI No.6/23/DPNP/2004)

Tabel 4. Kriteria Penetapan Peringkat Komponen Rentabilitas (NIM)

\begin{tabular}{|c|c|c|}
\hline Peringkat & Kriteria & Keterangan \\
\hline 1 & $>5 \%$ & Sangat Sehat \\
\hline 2 & $2,01 \%--5 \%$ & Sehat \\
\hline 3 & $1,5 \%-2 \%$ & Cukup Sehat \\
\hline 4 & $0 \%-1,49 \%$ & Kurang Sehat \\
\hline 5 & $<0 \%$ & Tidak Sehat \\
\hline
\end{tabular}

Sumber: Bank Indonesia

\section{Capital (Permodalan)}

Faktor yang terakhir dari komponen RGEC adalah Capital. Modal bank adalah sejumlah dana atau bentuk lain yang dimilki maupun dikuasai oleh lembaga usaha yang mempunyai fungsi untuk melaksanakan kegiatan produksi dalam menghasilkan pendapatan usaha. Rasio yang dapat mengukur faktor permodalan yaitu rasio CAR (Capital Adequacy Ratio). CAR adalah rasio kecukupan modal dikembangkan untuk memastikan bahwa bank-bank dapat menyerap tingkat kerugian yang wajar terjadi karena kerugian operasional dan menentukan kapasitas bank dalam memenuhi kerugian. Rasio CAR sendirididapatkan dengan membandingkan jumlah modal bank dengan aset Tertimbang Menurut Risiko (AMTR). 
$\mathrm{CAR}=$

Modal

x $100 \%$

Aktiva Tertimbang Menurut Risiko (ATMR)

Tabel 5. Kriteria Penetapan Peringkat Komponen Capital

\begin{tabular}{|c|c|c|}
\hline Peringkat & Kriteria & Keterangan \\
\hline 1 & $>15 \%$ & Sangat Sehat \\
\hline 2 & $9 \%-<15 \%$ & Sehat \\
\hline 3 & $8 \%-<9 \%$ & Cukup Sehat \\
\hline 4 & $\leq 8 \%$ & Kurang Sehat \\
\hline 5 & $<8 \%$ & Tidak Sehat \\
\hline
\end{tabular}

Sumber: Bank Indonesia

\section{Metode Penelitian}

Sugiyono menyatakan (2013:13), metode penelitian kuantitatif adalah metode penelitian yang berlandaskan pada filsafat positivisme, dipergunakan untuk meneliti pada populasi atau sampel tertentu, pengumpulan data dengan menggunakan instrument penelitian, analisis data bersifat kuantitatif/statistik, dengan tujuan untuk menguji hipotesis yang telah ditetapkan. Penelitian ini menggunakan metode deskriptif kuantitatif, yang dilakukan berdasarkan kinerja keuangan perbankan dengan menggunakan metode RGEC pada setiap laporan keuangan tahunan.Selanjutnya dilakukan perbandingan antara rata-rata rasio keuangan pada setiap laporan keuangan tahunan dengan standar Bank Indonesia.

\section{Populasi dan Sampel}

Menurut Sugiyono (2013:115), populasi adalah wilayah generalisasi yang terdiri atas objek atau subyek yang mempunyai kualitas dan karakteristik tertentu yang ditetapkan oleh peneliti untuk dipelajari dan kemudian ditarik kesimpulannya. Populasi dalam penelitian ini adalah laporan keuangan Bank BUMN, yaitu sebanyak 4 bank, yakni PT. Bank Rakyat Indonesia Tbk, PT. Bank Negara Indonesia Tbk, PT. Bank
Tabungan Negara Tbk, dan PT. Bank Mandiri Tbk dengan periode penelitian selama 3 tahun, dari tahun 2015 sampai 2017. Sampel adalah bagian dari jumlah dan karakteristik dari populasi tersebut Sedarmayanti (2011:123), sampel adalah kelompok kecil yang diamati dan merupakan bagian dari populasi sehingga sifat dan karakteristik populasi juga dimilki oleh sampel. Sampel penelitian ini adalah laporan keuangan Neraca dan Laba Rugi PT. Bank Rakyat Indonesia Tbk, PT. Bank Negara Indonesia Tbk, PT. Bank Tabungan Negara TBk, dan PT. Bank Mandiri Tbk periode tahun 20152017.

\section{E. Teknik Analisis Data}

Penelitian ini menggunakan metode analisis deskriptif kuantitatif, yaitu menjelaskan penilaian tingkat kesehatan bank dengan menggunakan metode RGEC (Risk Profile, GoodCorporate Governance, Earning, dan Capital).

1. Profil Risiko (Risk Profile)

Penilaian terhadap risiko terbagi menjadi 8 bagian, yaitu Risiko Kredit, Risiko Pasar, Risiko Likuiditas, Risiko Operasional, Risiko Hukum, Risiko strategi.

a. Risiko Kredit

$\mathrm{NPL}=\underline{\text { Kredit Bermasalah }} \times 100 \%$ Total Kredit 
b. Risiko Likuiditas

LDR $=$ Kredit yang diberikan $\times 100 \%$ Dana Pihak Ketiga

2. Good Corporate Governance (GCG) Penilaian faktor GCG merupakan penilaian terhadap kualitas manajemen Bank atas pelaksanaan prinsip-prinsip GCG.Prinsip-prinsip GCG dan fokus penilaian terhadap pelaksanaan berpedoman pada ketentuan Bank Indonesia, mengenai pelaksanaan GCG bagi Bank Umum dengan memperhatikan karakteristik dan kompleksitas usaha Bank (Surat
Edaran

Bank Indonesia

No.15/15/DPNP tahun 2013).

3. Earning (Rentabilitas)

a. Return On Assets (ROA)

$\mathrm{ROA}=$ Laba sebelum pajak $\times 100 \%$ Rata-rata Total Asset

b. Net Interest Margin (NIM)

$\mathrm{NIM}=$ Pendapatan Bunga Bersihx 100\% Rata-rata Aktiva Produktif

4. Capital

Capital atau permodalan adalah metode penilaian bank berdasarkan permodalan yang dimiliki bank dengan menggunakan rasio Capital Adequency

Ratio

(CAR).

$$
\mathrm{CAR}=\frac{\text { Modal }}{\text { Aktiva Tertimbang Menurut Risiko }}(\text { ATMR) }
$$

F. Hasil dan Pembahasan

\section{Analisis Metode RGEC pada Bank} Umum Pemerintah

Penilaian kesehatan bank dilakukan dengan menilai beberapa faktor berdasarkan indikator sehat atau tidak sehat. Penilaian kesehatan Bank meliputi faktor berikut :

1. Risk Profile pada Bank Umum Pemerintah
Rasio keuangan yang digunakan dalam menilai kinerja keuangan bank ditinjau dari aspek risk profile masing-masing dibahas dalam perhitungan sebagai berikut:

a) Resiko Kredit

Perhitungan

NPL

(Non

Performing Loan) khususnya pada PT. Bank umum pemerintah tahun 20152017 sebagai berikut ini:

Tabel 6. Bobot PK Komponen NPL (Non Performing Loan)

\begin{tabular}{|c|c|c|c|c|}
\hline Periode & BRI & BNI & BTN & Mandiri \\
\hline 2015 & $1,20 \%$ & $2,77 \%$ & $3,32 \%$ & $0,93 \%$ \\
\hline 2016 & $1,09 \%$ & $3,09 \%$ & $2,75 \%$ & $1,60 \%$ \\
\hline 2017 & $1,14 \%$ & $2,36 \%$ & $2,63 \%$ & $1,24 \%$ \\
\hline Peringkat & 1 (sangat sehat) & 2 (sehat) & 2 (sehat) & 1 (sangat sehat) \\
\hline
\end{tabular}

Sumber : Hasil Olahan Data 2017

b) Risiko Likuiditas

Pada penelitian ini untuk Ratio).

mengetahui risiko likuiditas dihitung

Tabel 7. Bobot PK Komponen LDR (Loan to Deposit Ratio)

\begin{tabular}{|c|c|c|c|c|}
\hline Periode & BRI & BNI & BTN & Mandiri \\
\hline 2015 & $84,28 \%$ & $70,26 \%$ & $140 \%$ & $90,69 \%$ \\
& (Sehat) & (Sangat Sehat) & Tidak Sehat & Cukup Sehat \\
\hline 2016 & $84,81 \%$ & $63,24 \%$ & $122 \%$ & $87,84 \%$ \\
& (Sehat) & (Sehat) & Tidak Sehat & Cukup Sehat \\
\hline 2017 & $84,57 \%$ & $44,85 \%$ & $103 \%$ & $90,48 \%$ \\
& (Sehat) & (Tidak Sehat) & Kurang Sehat & Cukup Sehat \\
\hline
\end{tabular}

Sumber : Hasil Olahan Data 2017 


\section{Good Corporate Governance (GCG) Bank Umum Pemerintah}

Penilaian terhadap faktor GCG merupakan penilaian terhadap manajemen bank atas elaksanaan prinsip-prinsip GCG sebagaimana diatur dalam Peraturan Bank Indonesia, GCG didasarkan pada 3 aspek utama yaitu Governance Structure, Governance Process, Governance Outcomes.

a) Governance Structure

Mencakup pelaksanaan tugas dan tanggung jawab Komisaris dan Direksi serta kelengkapan dan pelaksanaan tugas komite

b) Governance Process

Mencakup penerapan fungsi kepatuhan bank, penanganan benturan kepentingan, penerapan fungsi audit intern dan ekstern, penerapan manajemen risiko termasuk sistem pengendalian intern, penyediaan dana kepada pihak terkait dan dana besar, serta sistem rencana strategis bank.

c) Governance Outcomes

Mencakup transparansi kondisi keuagan dan non keuagan, laporan pelaksanaan GCG dan pelaporan internal.Penerapan GCG yang memadai sangat diperlukan dalam pengelolaan perbankan mengingat SDM yang menjalankan bisnis perbankan merupakan faktor kunci yang harus memiliki integritas dan kompetensi yang baik.

\section{Earning (Rentabilitas)}

Faktor rentabilitas terdiri atas 2 komponen pilihan yaitu Rasio Return On Assets (ROA) dan Net Interest Margin (NIM) yaitu:

Tabel 8. Bobot PK Komponen ROA (Return On Asset)

\begin{tabular}{|c|c|c|c|c|}
\hline Periode & BRI (\%) & BNI (\%) & BTN (\%) & Mandiri (\%) \\
\hline 2015 & $3,86 \%$ & $2,47 \%$ & $1,60 \%$ & $2,98 \%$ \\
& Sangat Sehat & Sehat & Sehat & Sangat Sehat \\
\hline 2016 & $3,68 \%$ & $2,57 \%$ & $1,72 \%$ & $1,90 \%$ \\
& Sangat Sehat & Sehat & Sehat & Sehat \\
\hline 2017 & $3,61 \%$ & $2,61 \%$ & $1,62 \%$ & $2,41 \%$ \\
& Sangat sehat & Sehat & Sehat & Sangat sehat \\
\hline
\end{tabular}

Sumber : Hasil Olahan Data 2017

Tabel 9. Bobot Peringkat Komposit NIM (Net Interest Margin)

\begin{tabular}{|c|c|c|c|c|}
\hline Periode & BRI & BNI & BTN & Mandiri \\
\hline 2015 & $7,87 \%$ & $7,05 \%$ & $11,06 \%$ & $6,58 \%$ \\
& Sangat Sehat & Sangat Sehat & Sangat sehat & Sangat sehat \\
\hline 2016 & $7,99 \%$ & $6,91 \%$ & $10,44 \%$ & $6,81 \%$ \\
& Sangat Sehat & Sangat Sehat & Sangat Sehat & Sangat Sehat \\
\hline 2017 & $7,93 \%$ & $6,28 \%$ & $9,49 \%$ & $6,21 \%$ \\
& Sangat Sehat & Sangat Sehat & Sangat Sehat & Sangat Sehat \\
\hline
\end{tabular}

Sumber : Hasil Data Olahan Tahun 2017

\section{Capital (Permodalan) Bank Umum Pemerintah}

Rasio yang digunakan dalam mengukur kecukupan modal adalah rasio CAR (Capital Adequency Ratio). 
Tabel 10. Bobot Peringkat Komposit CAR (Capital Adequency Ratio)

\begin{tabular}{|c|c|c|c|c|}
\hline Tahun & BRI & BNI & BTN & Mandiri \\
\hline 2015 & $20,58 \%$ & $22,40 \%$ & $16,96 \%$ & $18,60 \%$ \\
& Sangat Sehat & Sangat sehat & Sangat sehat & Sangat Sehat \\
\hline 2016 & $22,90 \%$ & $22,25 \%$ & $20,33 \%$ & $21,36 \%$ \\
& Sangat Sehat & Sangat sehat & Sangat Sehat & Sangat Sehat \\
\hline 2017 & $22,95 \%$ & $20,70 \%$ & $18,86 \%$ & $21,64 \%$ \\
& Sangat Sehat & Sangat sehat & Sangat Sehat & Sangat Sehat \\
\hline
\end{tabular}

Sumber : Data Hasil Olahan Tahun 2017

Kinerja keuangan Bank BRI dilihat dari rasio NPL masuk kategori sangat sehat dengan persentase $1,20 \%$ tahun $2015,1,09 \% 2016$, dan $1,14 \%$ 2017. Sama seperti NPL, dari segi rasio LDR Bank BRI masuk dalam kategori sangat sehat pada tahun 2015 dengan persentase $84,28 \%$ tahun 201684,81\% tahun 2017 $84,57 \%$. Untuk rasio ROA Bank BRI juga berada pada kategori sangat sehat pada tahun 2015 dengan persentase 3,86\%, $20163,68 \%$, dan 2017 dengan persentase 3,61\%, Dari segi permodalan diwakili rasio NIM Bank BRI juga tetap berada pada peringkat sangat sehat dengan persentase di tahun 2015 sebesar $7,87 \%, 2016$ sebesar 7,99\% dan ditahun 2017 sebesar 7,93\%. Dari segi permodalan diwakili rasio CAR, masuk dalam kategori sangat sehat ditahun 2015 20,58\%, 2016 22,90\%, dan ditahun 2017 22,95\%.

Kinerja keuangan Bank BNI dillihat dari rasio NPL termasuk dalam kategori sehat pada tahun 2015 dengan persentase $2,77 \%$, ditahun 2016 mengalami kenaikan sebesar $0,32 \%$ dengan persentase $3,09 \%$ dengan predikat sehat dan pada tahun 2017 mengalami penurunan sebesar $0,73 \%$ dengan persentase 2,36\% dengan predikat sehat. Pada rasio LDR Bank BNI ditahun 2015 dengan persentase sebesar $70,26 \%$ dengan peringkat sangat sehat, ditahun 2016 mengalami penurunan sebesar $7,02 \%$ dengan persentase sebesar $63,24 \%$ yang berada diperingkat sehat dan tahun 2017 dengan persentase $44,85 \%$ dengan predikat tidak sehat dan mengalami penurunan sebesar $18,39 \%$. Pada rasio ROA menunjukkan Bank BNI berada pada kategori sangat sehat pada tahun 2015 sebesar 2,47\%, 2016 2,57\%, dan tahun 2017 sebesar 2,61\%. Dari segi permodalan diwakili rasio NIM berada dalam kategori sangat sehat pada tahun $20157,05 \%$, 2016 6,91\%, dan 2017 6,28\%. Dari segi permodalan diwakili rasio CAR, masuk dalam kategori sangat sehat ditahun 2015 $22,40 \%, 2016 \% 22,25 \%$, dan ditahun $201720,70 \%$.

Kinerja keuangan Bank MANDIRI dillihat dari rasio NPL termasuk dalam kategori sangat sehat pada tahun 2015 dengan persentase $0,93 \%$, ditahun 2016 dengan persentase 1,60\% dengan predkat sehat dan pda tahun 2017 mengalami penurunan sebesar 1,24\%. Pada rasio LDR Bank Mandiri ditahun 2015 dengan predikat cukup sehat persentase sebesar $90,69 \%$, ditahun 2016 sebesar $87,84 \%$ dan tahun 2017 dengan persentase $90,48 \%$. Pada rasio ROA menunjukkan Bank MANDIRI berada pada kategori sangat sehat pada tahun 2015 sebesar 2,98\%, 2016 $1,90 \%$, dengan predikat sehat dan tahun 2017 sebesar 2,51\% dengan predikat sangat sehat. Dari segi permodalan diwakili rasio NIM berada dalam kategori sangat sehat pada tahun 2015 6,58\%, 2016 6,81\%, dan 
2017 6,21\%. Dari segi permodalan diwakili rasio CAR, masuk dalam kategori sangat sehat ditahun 2015 $18,60 \%$, $201621,36 \%$, dan ditahun $201721,64 \%$.

Kinerja keuangan Bank BTN dillihat dari rasio NPL termasuk dalam kategori sehat pada tahun 2015 dengan persentase $3,32 \%$, ditahun 2016 dengan persentase $2,75 \%$ dan pada tahun 2017 mengalami penurunan sebesar 2,63\%. LDR termasuk dalam kategori tidak sehat pada tahun 2015 dengan persentase $140 \%$, ditahun 2016 dengan kategori tidak sehat $122 \%$ dan pada tahun 2017 mengalami kenaikan sedikit sebesar $103 \%$ dengan predikat kurang sehat. Pada rasio ROA menunjukkan Bank BTN berada pada kategori sehat pada tahun 2015 sebesar 1,60\%, 2016 $1,72 \%$, dan tahun 2017 sebesar $1,62 \%$. Dari segi permodalan diwakili rasio NIM berada dalam kategori sangat sehat pada tahun 2015 11,06\%, $201610,44 \%$, dan 2017 $9,49 \%$. Dari segi permodalan diwakili rasio CAR, masuk dalam kategori sangat sehat ditahun 2015 16,96\%, $201620,33 \%$, dan ditahun 2017 $18,86 \%$

\section{G. Kesimpulan}

Berdasarkan hasil analisis perbandingan kinerja keuangan dengan menggunakan metode RGEC pada Bank Umum Pemerintah (BUMN) periode 2015-2017, dapat dihasilkan perolehan nilai rasio-rasio yang digunakan menghitung metode RGEC dinyatakan sehat dan sangat sehat untuk 4 bank umum pemerintah di BEI.

\section{DAFTAR PUSTAKA}

Basama. Monika 2017. Analisis Perbandingan Tingkat Kesehatan Bank dengan Metode RGEC Di
Indonesia (Studi Komparatif: Bank BUMN, Bank Swasta Nasional, dan Bank Asing Tahun 2013-2015). E-jurnal, Universitas Lampung.

Daniswara, Fitria. 2016. Analisis Perbandingan Kinerja Keuangan Berdasarkan Risk Profile, Good Corporate Governance, Earnings, and Capital (RGEC) Pada Bank Umum Konvensional dan Bank Umum Syariah Periode 20112014. E-jurnal, Universitas Sebelas Maret.

Fahmi, Irham. 2017. AnalisisLaporanKeuangan, Alfabeta, Bandung.

Hasibuan P. Malayu. 2014. DasarDasar Perbankan. PT. BumiAksara, Jakarta.

Iskandar.Syamsu. 2013.Bank dan Lembaga Keuangan Lainnya.In Media. Jakarta.

Ismail. 2015. Akuntansi Bank dan Teori dan Aplikasi dalam Rupiah. Prenada Media. Jakarta

Kasmir, 2014.Bank dan Lembaga Keuangan Lainnya, Rajawali Pres, Jakarta.

Korompis, Vanessa Elisabeth dkk. 2015. Analisis Perbandingan Tingkat Kesehatan Bank Berdasarkan Metode RGEC (Studi pada PT. Bank Rakyat Indonesia Tbk, dan PT. Bank Mandiri, Tbk Tahun 2012-2014). E.jurnal, Universitas Sam Ratulangi.

Mandasari.Jayanti 2015. Analisis Kinerja Keuangan dengan Pendekatan Metode RGEC Pada 
Bank BUMN Periode 2012-2013. E-jurnal,

Universitas Mulawarman.

Norrahmiati. 2017. Analisis Komperatif Kinerja Keuangan Berdasarkan Metode RGEC Pada Perusahaan Perbankan Yang Terdaftar di Bursa Efek Indonesia.E-jurnal, Universitas Achmad Yani Banjarmasin.

Sedarmayanti. Hidayat, Syaifudin. 2011. Metodologi Penelitian, CV. Madar Maju. Bandung
Sugiyono. 2013. MetodePenelitianBisnis, abeta, Bandung.

Sugiyono. 2017. Metode Penelitian Kuantitatif, Kualitatif, dan R\&D. Bandung: ALFABETA

Surat Edaran Bank Indonesia. 2011. Lampiran Surat Edaran Bank Indonesia Nomor 13, 24/DPNP Tanggal 25 Oktober 2011 tentang Penilaian Tingkat Kesehatan Bank, Jakarta, Bank Indonesia. 